九州大学学術情報リポジトリ

Kyushu University Institutional Repository

Distribution of Asteralobia Gall Midges (Diptera: Cecidomyiidae) Causing Axillary Bud Galls on Ilex Species (Aquifoliaceae) in Japan

Tokuda, Makoto

Uechi, Nami

Yukawa, Junichi

https://doi.org/10.5109/2658

出版情報: ESAKIA. 42，pp.19-31，2002-03-31. Entomological Laboratory，Faculty of Agriculture， Kyushu University

バージョン：

権利関係 : 


\title{
Distribution of Asteralobia Gall Midges (Diptera: Cecidomyiidae) Causing Axillary Bud Galls on Ilex Species (Aquifoliaceae) in Japan*
}

\author{
Makoto TOKUDA, Nami UECHI \\ Kyushu University, Fukuoka, 812-8581 Japan \\ and \\ Junichi YUKAWA \\ Entomological Laboratory, Faculty of Agriculture, \\ Kyushu University, Fukuoka, 812-8581 Japan
}

Entomological Laboratory, Graduate School of Bioresource and Bioenvironmental Sciences,

\begin{abstract}
We revised and analyzed distributional information on two nominal and some unidentified Japanese Asteralobia species that produce axillary bud galls on Ilex species (Aquifoliaceae). Galls on I. maximowicziana are newly recorded from the Southwest Islands. Galls produced by respective Asteralobia species were collected from most of the distribution range of their host plants, whilst those on I. integra and on I. goshiensis were not found in some localities within the distribution range of the host plants. A wide and common distribution range of Asteralobia sasakii on I. crenata, I. crenata var. paludosa, and I. maximowicziana suggested a high dispersal ability of the species. Distribution patterns of Asteralobia soyogo on I. chinensis, I. integra, and I. pedunculosa indicated a possible host plant preference by the gall midge. An unidentified gall midge associated with $I$. warburgi is widely distributed in the Southwest Islands and gall dissection data as to age structure indicated that the gall midge might be different from $A$. sasakii.
\end{abstract}

Key words: Asteralobia, axillary bud gall, Cecidomyiidae, distribution, gall midge, Ilex.

* Contribution from the Entomological Laboratory, Faculty of Agriculture, Kyushu University, Fukuoka (Ser. 5, No. 77) 


\section{Introduction}

In gall-making cecidomyiids, some of closely related species are known to produce, respectively, a similar sort of gall on different plant species within a single or related plant genera. In Japan, examples have been shown in Asteralobia gall midges on Ilex species (Aquifoliaceae) (Yukawa \& Masuda, 1996) and Lasioptera gall midges on wild gourds (Miyatake et al., 2000). In this paper, we refer to the Asteralobia gall midges on Ilex. They are suitable materials to study a possible process of speciation or host race formation in herbivores.

The genus Asteralobia consists of 10 species in the world, five of them being distributed in Japan and the remainders in Russian Far East (Kovalev, 1964; Yukawa, 1971; Yukawa, 1983). Among them, two Japanese species are associated with Ilex species (Yukawa, 1971; Yukawa \& Masuda, 1996). Asteralobia sasakii (Monzen) makes axillary bud galls on Ilex crenata Thunb. (Monzen, 1937) and Asteralobia soyogo (Kikuti) on Ilex pedunculosa Miq. (Kikuti, 1939). Thereafter, a similar sort of axillary bud gall caused by congeneric cecidomyiids was successively found on I. chinensis Sims., I. crenata var. paludosa (Nakai) Hara, I. goshiensis Hayata, I. integra Thunb., I. leucoclada (Maxim.) Makino, I. liukiuensis Loes., and I. warburgi Loes. (Shinji, 1944; Yukawa, 1976; Yamauchi et al., 1982; Yukawa, 1982; Yukawa \& Sunose, 1988; Yukawa \& Masuda, 1996). These cecidomyiids were tentatively included in $A$. sasakii in Yukawa \& Masuda (1996), but their morphological features have never been compared among gall midges on different host species and the distributional information of respective gall midges has been fragmentary.

In order to identify these gall midges at the species level and to approach the process of speciation or host race formation, we have to synthesize various information such as their distribution range, morphological characters, DNA sequences, and other ecological data.

In this paper, we refer to the distribution range of respective Japanese Asteralobia gall midges on different Ilex species, as the first step toward a future evolutionary study. Distributional information, when combined with phylogenetic relations, will serve to analyze the shift of distribution range.

\section{Materials and Methods}

We collected axillary bud galls on Ilex spp. at various localities in Japan. Our colleagues also gave us many galls and their distributional information. Some of the collected galls were dissected under a binocular microscope to obtain larval and pupal specimens. Remaining galls were maintained in plastic containers (15 cm in diameter, $25 \mathrm{~cm}$ in depth) to rear adult midges. Mature larvae, pupae, and emerged adults were put into $75 \%$ ethanol 
for morphological observation and $99.5 \%$ acetone for DNA analysis.

In the present paper, we arranged the collecting records of Asteralobia midge galls according to the alphabetical order of plant species. Each collecting record consists of host plant, locality, collecting date, collector, developmental stages of the gall midge, and some other biological information. The names of Japanese main islands are abbreviated in brackets as HK (Hokkaido), HS (Honshu), SH (Shikoku), KY (Kyushu), and SW (the Southwest Islands south of Yakushima Is.), and followed by the names of prefectures. The names of locality with an asterisk mean that the galls have previously been recorded in the same place. The collecting dates with a plus mark mean that the galls were collected there more than one time.

Some collector's names are abbreviated as follows: IM (=I. Matoba), HN (=H. Nishio), JY (=J. Yukawa), MT (=M. Tokuda), MY (=M. Yukinari), NU (=N. Uechi), and TS (= T. Sunose).

Localities where Ilex galls were found in the previous and present field surveys were plotted on maps to indicate the distribution range of respective gall midges. Upon the maps, we illustrated the distribution range of respective host plants based on Hatusima (1971), Horikawa (1972), and Yamazaki (1989).

The gall midges associated with I. goshiensis and I. liukiuensis have never been identified due to the lack of their adult specimens (Yukawa \& Masuda, 1996). Because the structure and size of their galls are somewhat different from those on other Ilex spp. (Yamauchi et al., 1982; Yukawa \& Masuda, 1996), they may not belong to the genus Asteralobia. However, we included their distributional information in this paper.

\section{Results}

Ilex chinensis (Fig. 1A) [see also Yukawa, 1988]

[HS: Kyoto]: Kamigyo-ku, Kyoto City, 18 Oct. 1975, K. Ohara; Sakyo-ku, Kyoto City, 18 Oct. 1978, H. Ikenaga, 3rd instars; [HS: Wakayama]: Nakano, Kanaya Town, 10 Mar. 2002, JY \& IM, 3rd instars; Mt. Funaokayama, Katsuragi Town, 10 Mar. 2002, A. Yamamoto, 3rd instars; Saya, Katsuragi Town, 17 Mar. 2002, A. Yamamoto, 3rd instars; Sandanbeki, Shirahama Town, 9 Aug. 1999, JY, young larvae; [HS: Okayama]: Uetsukinaka, Shouou Town, 14 Oct. 1978, JY, 3rd instars; [SH: Tokushima]: Maeyama Park, Ishii Town, 15 Oct. 2001, MY, 3rd instars; [KY: Fukuoka]: Aobanomori Park, Fukuoka City, 27 Apr. 2000+, MT \& NU, pupae; Mt. Sefuriyama, Fukuoka City, 25 Apr. 1967+, A. Nakanishi, adults; Mt. Tachibanayama, Fukuoka City, 17 Mar. 2002+, NU, 3rd instars; Ino, Hisayama Town, 4 Apr. 2001+, MT \& NU, 3rd instars; Kurogi Town, 3 Jan. 1975, K. Takahashi, 3rd instars; Kyushu Univ. Forest, Sasaguri Town, 20 Oct. 2001+, MT \& NU, 3rd instars; Miyajidake, 
Tsuyazaki Town, 6 Jan. 2002, HN, 3rd instars; [KY: Nagasaki]: Hei, Futsu Town, 12 May 2000, MT \& JY, old galls; [KY: Oita]: Usa Shrine, Usa City, 19 Sep. 1997, JY, 2nd instars; Mure, Mie Town, 20 Mar. 2002, MT \& JY, 3rd instars; [KY; Miyazaki]: Morotsuka Village, Mar. 1978, T. Sanui, old galls; [KY: Kagoshima]: Shiroyama*, Kagoshima City, 27 Nov. 2001+, JY, 3rd instars.

Ilex crenata (Fig. 1B) [see also Ijichi, 1937; Yano, 1964; Sunose, 1981; Tamura, 1966; Usuba, 1979; Yukawa, 1971; Yukawa, 1988; Yukawa \& Sunose 1988]

[HS: Miyagi]: Mt. Aobayama, Sendai City, 22 Sep. 2001, MT \& JY, 2nd instars; [HIS: Fukushima] Soma City, 12 Feb. 1973, TS, 3rd instars; [HS: Saitama]: Kamio City, 5 Nov. 1974, TS, 3rd instars; [HS: Chiba]: Lake Toyofusako, Kimitsu City, 31 Mar. 2002, MT \& JY, 3rd instars; Chiba Univ., Matsudo City, 4 Apr. 2000+, K. Tabuchi, 3rd instars; [HS: Tokyo] Hachijo-fuji, Hachijo Town*, Hachijojima Is., Jan. 2002, H. Sato, 3rd instars; [HS: Kanagawa]: Yokoyama, Sagamihara City, 8 Apr. 1988, Y. Yamashita \& M. Okabe, adults emerged on 7 May reared by Y. Yamashita \& S. Takasugi; [HS: Shizuoka]: Futo, Ito City, 3 Feb. 2002, K. Kiritani, 3rd instars; [HIS: Aichi] : Seto City, 25 May 2000, K. Tabuchi, Adults; [HS: Wakayama]: Akanuma, Kainan City, 10 Mar. 2002, JY \& IM, 3rd instars; Tanabe City, Mar. 1971, S. Gotoh, 3rd instars; Sando; Wakayama City, 15 Apr. 1975, K. Yamagishi, 3rd instars; Kaseda-higashi, Katsuragi Town, 17 Mar. 2002, A. Yamamoto, 3rd instars; [HS: Kyoto]: Mt. Daimonjiyama, Kyoto City, 14 Mar. 2000, NU, 3rd instars; Yonaki-toge, Kyoto City, 21 Apr. 2001, Y. Abe, pupae (adults emerged on 12 May 2001, reared by MT); [HS: Okayama]: Mt. Tsurugatayama, Kurashiki City, 11 Oct. 1978, JY; Tanokuma, Tsuyama City, 14 Oct. 1978, H. Ikenaga, 2nd \& 3rd instars; [HS: Hiroshima]: Mt. Garyuyama, Geihoku Town, 3 Jun. 1967, JY; [SH: Tokushima]: Kamiyama Forest Park, Kamiyama Town, 15 Oct. 2001, MY, 3rd instars; [SH: Ehime]: Omogokei, Omogo Town, 11 May 1969, JY; [SH: Kochi]: Anauchi, Otoyo Town, 5 Dec. 2001, MT, 3rd instars; Kajigamori*, Otoyo Town, 5 Dec. 2001, MT, 3rd instars; Hiraishi, Tosa Town, 5 Dec. 2001, MT, old galls; Kamiyoshihara, Kagami Village, 5 Dec. 2001, MT, old galls; [KY: Fukuoka]: Mt.

Fig. 1. A-D: Collection records of axillary bud galls on Ilex spp. caused by Asteralobia gall midges; host plant - : I. chinensis, \$: I. crenata, 污: I. crenata var. paludosa, A: I. leucoclada, : I. integra, : I. pedunculosa.

The shaded area in Fig. 1A, 1B, 1C, and 1D indicates the distribution range of I. chinensis, I. crenata, I. integra, and I. pedunculosa, respectively. The area surrounded by a broken line in Fig $1 \mathrm{~B}$ and $1 \mathrm{C}$ indicates the distribution range of I. crenata var. paludosa and I. leucoclada, respectively.

*The Southwest Islands. 


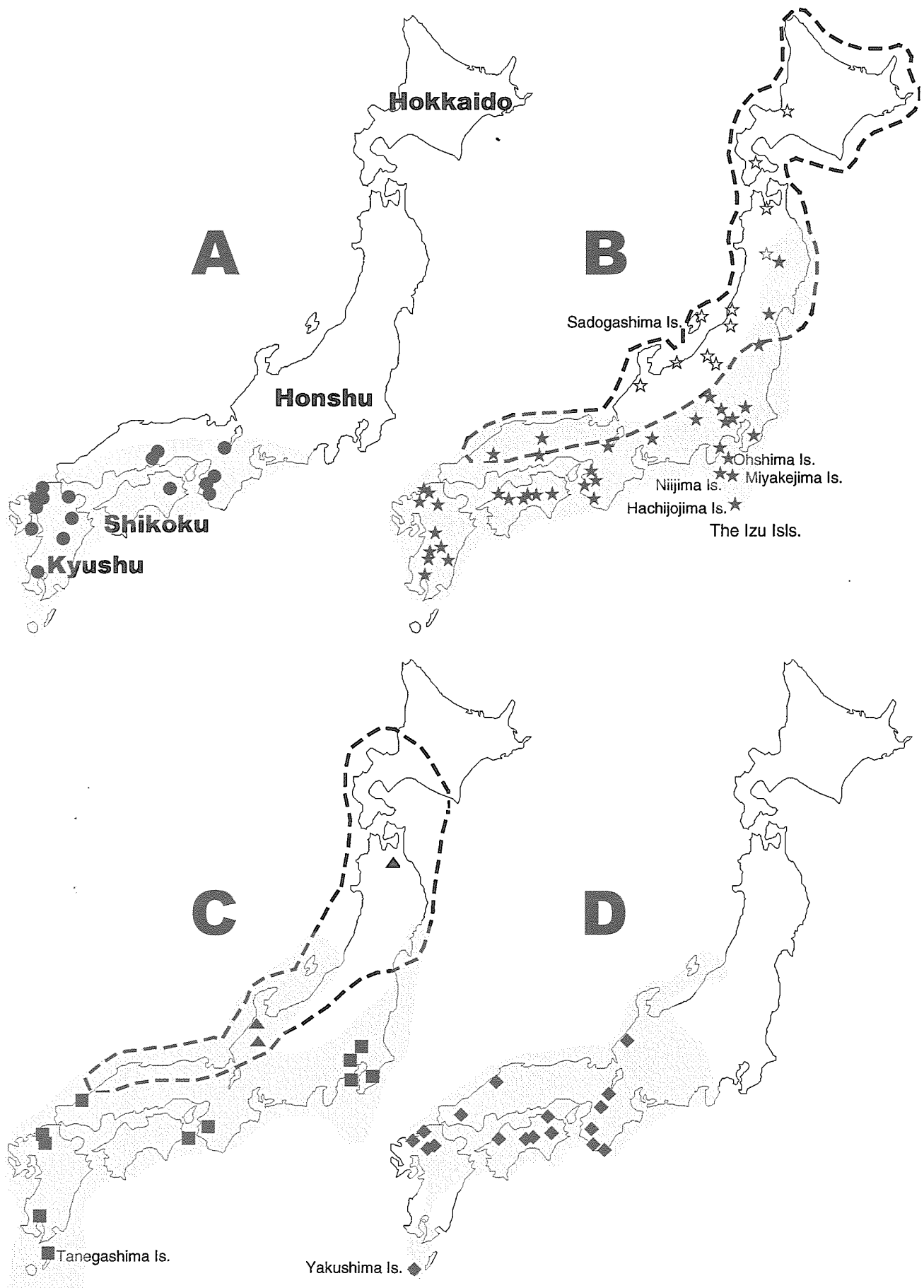

SW* 
Sefuriyama, Fukuoka City, 26 May 1967, A. Nakanishi, pupae \& adults; Mt. Tachibanayama, Fukuoka City, 25 May 2001, MT, pupae; Ino, Hisayama Town, 4 Apr. 2001+, MT, 3rd instars; Mt. Hikosan*, Soeda Town, 19 Jun. 2000, MT, old galls; [KY: Kumamoto]: Otsuka, Hitoyoshi City, 4 May 2001, JY, old galls; Mt. Kyonojosan, Tomochi Town, 5 May 1981, J. Onagamitsu, old galls; [KY: Miyazaki]: Kyushu Univ. Forest, Shiiba Village, 27 May 1969, S. Hatusima, adults emerged on 17 and 18 Jun. reared by JY; [KY: Kagoshima]: Nishi-sakurajima, Sakurajima Town, 4 Mar. 1973, TS, 3rd instars; Mt. Kurinodake, Kurino Town, 6 Jun. 1971, K. Ohara, old galls.

Ilex crenata var.paludosa (= Ilex crenata subsp. radicans) (Fig. 1B) [see also Yukawa, 1976; Yukawa \& Sunose, 1979; Sunose, 1982; Yukawa \& Sunose, 1988; Yukawa, 1994] [HK]: Hitsujigaoka, Sapporo City, 12 Oct. 1975, K. Yamagishi, 3rd instars; Hokkaido Univ. Botanical Garden, Sapporo City, 27 Jun. 2001, M. Shoubu, all galls contained larvae of an unidentified hymenopteran ectoparasitoid; [HS: Aomori]: Moya, Aomori City, 19 Jun. 2000, E. Kimura \& S. Fukuda, pupae; [HS: Akita]: Obonai, Tazawako Town, 24 Jun. 1975, K. Yamagishi, 1st \& 2nd instars.

Ilex goshiensis (Fig. 2A) [see also Yamauchi et al., 1982]

[SW: Okimawa]: Banna Park, Ishigaki City, Ishigakijima Is., 9 Mar. 2002, MT, 3rd instars; Mt. Omotodake, Ishigaki City, Ishigakijima Is., 10 Mar. 2002, MT, 3rd instars.

Ilex integra (Fig. 1C) [see also Usuba, 1979; Yukawa, 1988; Yukawa et al., 2000]

[HIS: Chiba]: Chiba Univ., Matsudo City, early May 2001+, K. Tabuchi, adults; [HHS: Kanagawa]: Bishamon, Miura City, 3 Jan. 2002, M. Sueyoshi, 3rd instars; [HS: Wakayama]: Miyazaki, Arida City, 10 Mar. 2002, JY \& IM, 3rd instars; [HS: Yamaguchi]: Susa Town, 3 Apr. 2001, MT \& JY, old galls; [SH: Tokushima] : Ishima Is., Anan City, 6 Jun. 2001, MY, old galls; [KY: Fuknoka]: Maizuru Park, Fukuoka City, 15 Mar. 2000+, MT \& NU; Minami Park, Fukuoka City, 18 Jun. 2001, NU, old galls; Miyazaki, Chikushino City, 4 Jan. 2002, HN, 3rd instars; [KY: Kagoshima]: Ryugamizu, Kagoshima City, 4 Nov. 1969, A. Mori, old galls; Nishinoomote, Nishino-omote City, Tanegashima Is., 23 Feb. 2001+, K. Ogata, 3rd instars.

Ilex leucoclada (Fig. 1C) [see also Yukawa, 1982]

Fig. 2. A-C: Collection records of axillary bud galls on Ilex spp. caused by Asteralobia gall midges; host plant - : I. goshiensis, $\mathbb{\Delta}$ : I. liukiuensis, $:$ I. warburgii, $\star$ : I. maximowicziana, th: I. maximowicziana var. kanehirae.

The shaded area in Fig. 2A, 2B, and 2C indicates the distribution range of $I$. goshiensis, $I$. liukiuensis, and I. maximowicziana, respectively. The area surrounded by a broken line in Fig. $2 \mathrm{~B}$ and $2 \mathrm{C}$ indicates the distribution range of $I$. warburgii and $I$. maximowicziana var. kanehirae, respectively. 
DISTRIBUTION OF ASTERALOBIA GALL MIDGES ON ILEX

25

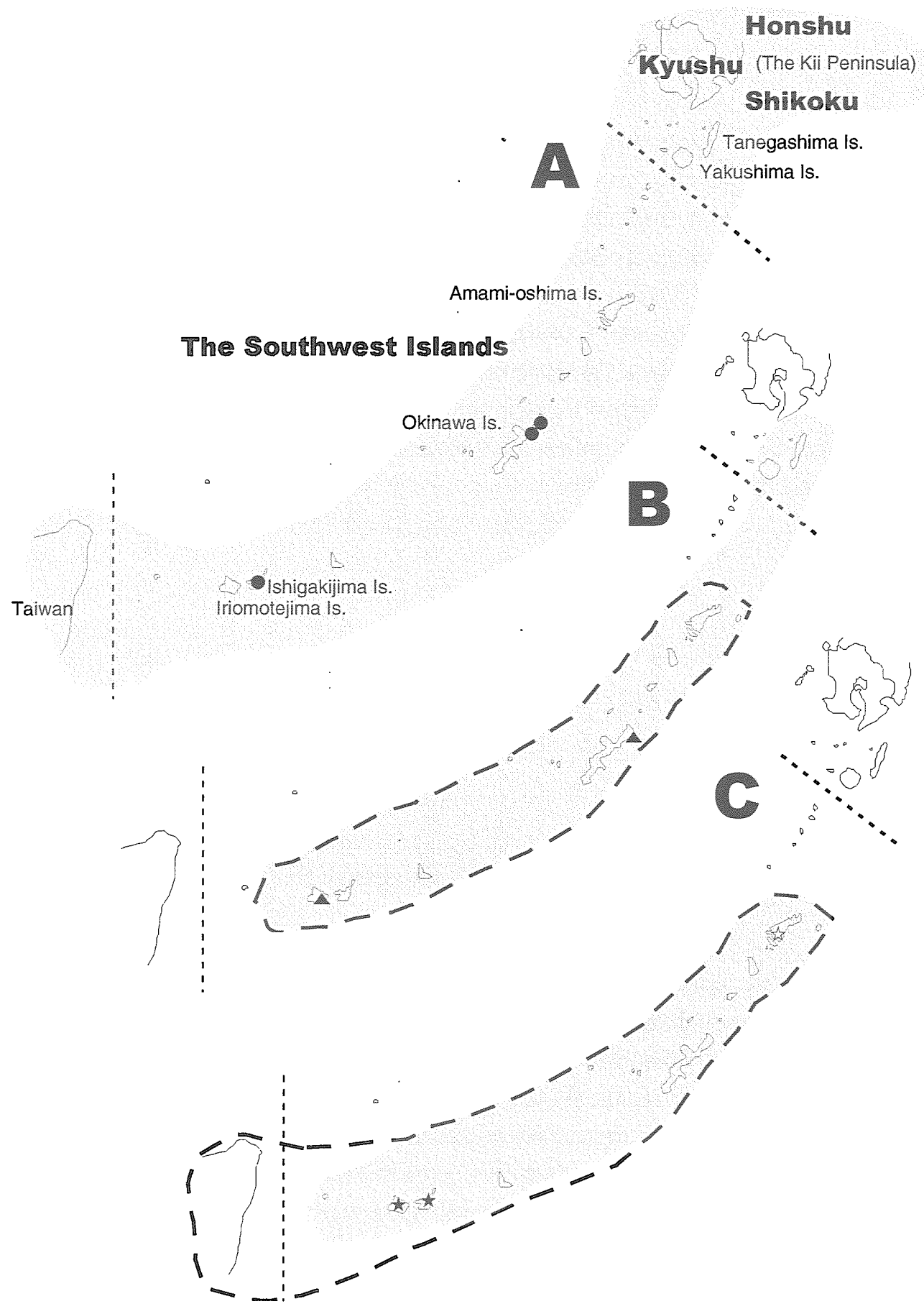


[HHS: Aomori]: Towadako Town, 16 Nov. 1996, E. Kimura \& S. Fukuda, 3rd instars; [HS: Ishikawa]: Mt. Fujishagadake, Yamanaka Town, 10 May 1988, I. Togashi, adults emerged on 25 May reared by I. Togashi.

Ilex liukiuensis (Fig. 2B) [see also Yamauchi et al., 1982]

[SW: Okinawa]: Urauchi Riv., Taketomi Town, Iriomotejima Is., 7 Mar. 2002, MT, old galls; Aira Riv., Taketomi Town, Iriomotejima Is., 7 Mar. 2002, MT, old galls.

Ilex maximowicziana Loes. (New gall record) (Figs. 2C \& 3)

[SW: Okinawa]: Banna Mountain Highway, Ishigaki City, Ishigakijima Is., 9 Mar. 2002, MT, pupae; Banna Park, Ishigaki City, Ishigakijima Is., 2 Mar. 2001+, MT \& NU, pupae; Mt. Omotodake, Ishigaki City, Ishigakijima Is., 25 Feb. 2001+, MT \& NU, 3rd instars \& pupae; Aira Riv., Taketomi Town, Iriomotejima Is., 7 Mar. 2002, MT, 3rd instars; Komi, Taketomi Town, Iriomotejima Is., 1 Mar. 2001, MT \& NU, pupae; Takana, Taketomi Town, Iriomotejima Is., 7 Mar. 2002, MT, 3rd instars; Urauchi Riv., Taketomi Town, Iriomotejima Is., 7 Mar. 2002, MT, old galls.

Remarks: The axillary bud is transformed into a subglobular swelling (Fig. 3); usually 8 to 15 larvae inhabiting each gall; gall size: $13.7 \mathrm{~mm}$ in mean maximum diameter, 8.5-20.0mm in range $(\mathrm{N}=18$; galls collected from Ishigakijima Is. and Iriomotejima Is. in 2001, taken together). Adults emerged from 11 to $18 \mathrm{March}$ 2002 from the galls collected by MT on 9 and 10 March 2002 from Banna Park and Mt. Omotodake, Ishigakijima Is. A photograph, which was taken by Mr. Itsuro Katanoda in Uken Village, Amami-oshima Is. (Katanoda, 1999), clearly indicates the occurrence of the axillary bud galls on Ilex maximowicziana var. kanehirae (Yamamoto) Yamazaki on Amami-oshima Is, although actual galls were not collected previously on that island.

Ilex pedunculosa (Fig. 1D) [see also Yano, 1964; Yukawa, 1971; Yukawa, 1988]

[HS: Ishikawa]: Mt. Kurakakeyama, Komatsu City, 17 Mar. 2002, I. Honda, 3rd instars; [HS: Kyoto]: Mt. Kazan*, Kyoto City, 12 Mar. 2000+, NU \& Y. Tohsaka, 3rd instars; [HS: Wakayama]: Shiono-misaki, Kushimoto Town, 17 Feb. 1976, TS, 3rd instars; Kotonotaki, Susami Town, 5 May 2001, M. Shoubu, pupae; Akanuma, Kainan City, 10 Mar. 2002, JY \& IM, 3rd instars; [HIS: Shimane]: Hitokubota, Sada Town, 2 Apr. 2001, MT \& JY, old galls; [HS: Yamaguchi]: Omine-cho, Mine City, 3 Jan. 2002, MT, 3rd instar; [SH: Kagawa]: Saiho, Takamatsu City, 2 Oct. 1990, JY, 2nd instars; [SH: Tokushima]: Kamiyama Forest Park, Kamiyama Town, 15 Oct. 2001, MY, 3rd instars; [SH: Kochi]: Kajigamori*, Otoyo Town, 5 Dec. 2001, MT, old galls; Osugi, Otoyo Town, 5 Dec. 2001, MT, 3rd instars; [KY: Fukuoka]: Mizunashi, Maebaru City, 5 May 1965, Y. Miyatake; Mt. Toriyayama, Amagi City, 26 Feb. 2002, N. Kuroiwa \& HN, 3rd instars; Mt. Hikosan, Soeda Town, 25 Oct. 2001, MT \& NU, 3rd instars; Miyajidake, Tsuyazaki Town, 6 Jan. 2002, HN, 3rd 


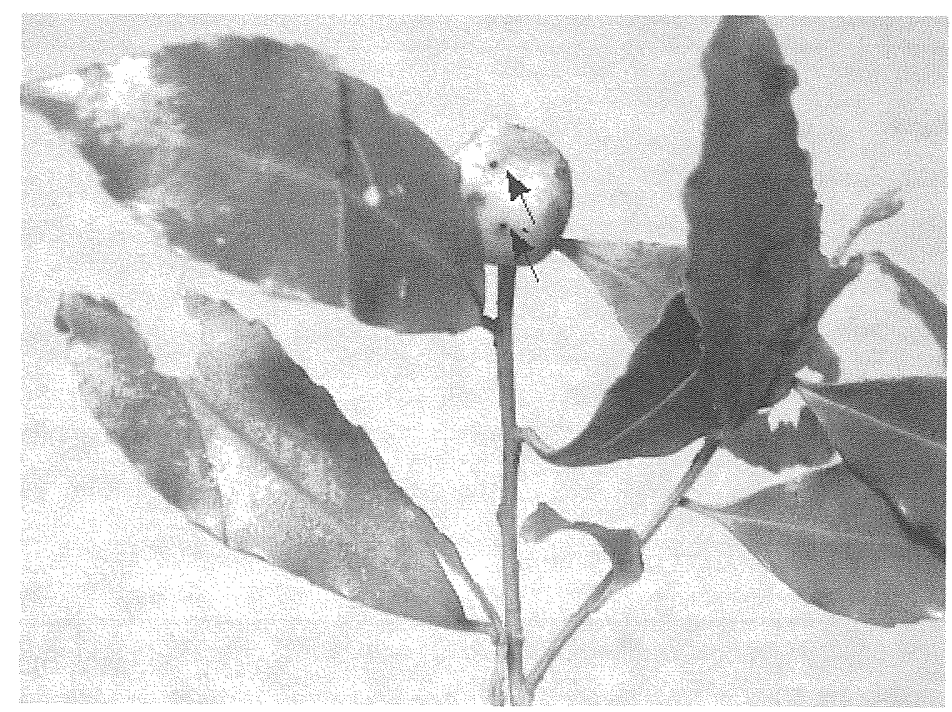

Fig. 3. An axillary bud gall caused by Asteralobia sp. on Ilex maximowicziana. Arrows point toward the exit holes of the gall midge.

instars.

Ilex warburgi (Fig. 2B) [see also Yamauchi et al., 1982]

[SW: Kagoshima]: Kamiya, Sumiyo Village, Amamioshima Is., 28 Mar. 2002, Y. Sato, 3rd instars; [SW: Okinawa]: Banna Park, Ishigaki City, Ishigakijima Is., 2 Mar. 2001+, MT \& NU, 3rd instars; Komi, Taketomi Town, Iriomotejima Is., 1 Mar. 2001, MT \& NU, 3rd instars.

\section{Discussion}

The distribution range of Asteralobia gall midges is summarized in Table 1. The gall midges were collected from most of the distribution range of respective host plants. Although axillary bud galls have never been found on I. leucoclada in Hokkaido, and on I. liukiuensis on Tanegashima Is. and Yakushima Is., more frequent field surveys will provide us with further information in these areas.

Galls on I. integra have never been recorded from the Southwest Islands and those on I. goshiensis in Honshu, Shikoku, and Kyushu, even though frequent surveys have been performed (e.g. Yamauchi et al., 1982; Yukawa, 1976; Yukawa, 1988; present data). The main difficulty in talking about the distribution range of a species is the reliance to be placed on absences. A species may be erroneously recorded as absent when collecting has been insufficient or at the wrong season, or when a species is rare (Yukawa, 1984). In the 
Table 1. Distribution range of gall midges producing axillary bud galls on Ilex in Japan.

\begin{tabular}{lccccc}
\hline Host plant & HK & HS & SH & KY & SW \\
\hline I. chinensis & - & - & 0 & - & - \\
I. crenata & - & 0 & - & 0 & - \\
I. c. var. paludosa & - & - & - & - & - \\
I. goshiensis & - & $\bigcirc$ & $\bigcirc$ & $\bigcirc$ & 0 \\
I. integra & - & - & - & 0 & $\bigcirc$ \\
I. leucoclada & - & - & - & - & - \\
I. liukiuensis & - & - & - & $\bigcirc *$ & 0 \\
I. maximowicziana & - & - & - & - & 0 \\
I. m. var. kanehirae & - & - & - & - & 0 \\
I. pedunculosa & - & - & - & 0 & - \\
I. warburgi & - & - & - & - & 0 \\
\hline \hline
\end{tabular}

Abbreviations and symbols indicated in Table 1 are as follows: HK: Hokkaido; HS: Honshu; SH: Shikoku; KY: Kyushu; SW: The Southwest Islands; - : Host plant is not distributed; $\bigcirc$ : Host plant is distributed but gall midge has never been recorded; : Both host plant and gall midge are distributed.

* Host plant is distributed only on Tanegashima Is. and Yakushima Is.

case of gall midges associated with Ilex spp., we can easily find galls at any seasons because galls remain on the host trees long after the event of galling (Yukawa \& Masuda, 1996). In addition, galls on other Ilex spp. than I. integra and I. goshiensis were frequently found in the Southwest Islands and in Honshu, Shikoku, and Kyushu, respectively (Figs. $1 \& 2$ ). Therefore, these gall midges may well be absent from aforementioned areas. If so, these distribution patterns, when combined with phylogenetic data, will contribute to discussing host plant and distribution range shift by the respective cecidomyiid species.

Our preliminary data of DNA analysis (Tokuda \& Yukawa, unpublished data) indicate that gall midges associated with $I$. crenata var.paludosa, and $I$. maximowicziana are possibly identical with $A$. sasakii on $I$. crenata. This gall midge is distributed most widely and commonly in Japan including Sadogashima Is. (Yukawa \& Sunose 1988) and the Izu Isls. (Sunose, 1981) (Figs. 1B \& 2C). Such a wide and common distribution pattern seems to suggest that the gall midge has a high dispersal ability compared to others.

Gall midges associated with $I$. chinensis and I. integra are mainly distributed in Shikoku, Kyushu, and western parts of Honshu (Figs. 1A \& 1C). Based on adult morphology and DNA analysis (Tokuda \& Yukawa, unpublished data), we suspect that these two gall midges are identical with $A$. soyogo that produces axillary bud galls on $I$. pedunculosa in the same areas (Fig. 1D).

Ilex integra is distributed widely in Japan except Hokkaido and northern parts of Honshu (Fig. 1C; Horikawa, 1972), but the galls on this plant have been collected from some 
restricted parts of eastern Honshu (Chiba and Kanagawa Prefectures) and Tanegashima Is. (Kagoshima Prefecture) (Fig. 1C), where I. chinensis and I. pedunculosa are not distributed (Figs. 1A \& 1D). Similarly in Kyushu, we collected galls from I. integra at several localities where both $I$. chinensis and I. pedunculosa were not found. In addition, many galls were found on I. pedunculosa trees but not on I. integra trees, even though they (a total of 130 trees) grow sympatrically at Kamiyama Forèst Park (Kamiyama Town, Tokushima Prefecture) (Masaaki Yukinari, 2001, personal communication). At Ino (Hisayama Town, Fukuoka Prefecture), we observed a similar phenomenon between co-existing I. chinensis and $I$. integra trees. The former bears galls but the latter does not. These results suggest a possibility that $A$. soyogo prefers $I$. pedunculosa and I. chinensis to I. integra for galling.

An unidentified gall midge associated with $I$. warburgi is widely distributed in the Southwest Islands (Fig. 2B). This species was still 3rd instar in early March when $A$. sasakii already pupated in the galls on $I$. maximowicziana in Ishigakijima Is. and Iriomotejima Is. Therefore, this gall midge seems to emerge later in the season than $A$. sasakii, suggesting that they are temporally isolated and not identical.

\section{Acknowledgements}

We wish to express our thanks to Dr. S. Kobayashi (Faculty of Science, Kyushu Univ.) for identifing Ilex species collected from Ishigakijima Is. and Iriomotejima Is. and to Mr. M. Yukinari (Tokushima City) for giving us useful host information and galls on Ilex at Kamiyama Forest Park, Tokushima Prefecture. Our thanks are also due to the following persons for offering materials: Dr. Y. Abe (Kyoto Pref. Univ.), Mr. S. Fukuda (Hachinohe City), Mr. S. Gotoh (Tanabe City), Dr. S. Hatusima (Prof. Emeritus at Kagoshima Univ.), Mr. I. Honda (Ishikawa Pref.), Mr. H. Ikenaga (Nat. Food Res. Inst.), Ms. E. Kimura (Aomori City), Dr. K. Kiritani (Ito City), Ms. N. Kuroiwa (Fukuoka Pref.), Mr. I. Matoba (Wakayama Pref. Mus. of Nat. Hist.), Prof. Y. Miyatake (Osaka Aoyama Junior College), Dr. A. Mori (Univ. of Notre Dame, USA), Prof. A. Nakanishi (Mus. of Nature \& Human Activities, Hyogo), Ms. H. Nishio (Fukuoka Pref.), Mr. K. Ogata (Nishino-omote City), Mr. K. Ohara (Tokushima Pref. Mus.), Mr. M. Okabe (Kanagawa Pref.), Mr. J. Onagamitsu (Fukuoka Pref. Forest Res. \& Ext. Cen.), Mr. T. Sanui (Forest Exp. Stn. Miyazaki Pref.), Dr. H. Sato (Forestry \& Forest Reproduct Res. Inst.), Mr. Y. Sato (Kagoshima Pref. Forest Exp. Stn.), Miss M. Shoubu (Entomological Laboratory, Kyushu Univ.), Dr. M. Sueyoshi (Japanese Science and Technology Corporation: Domestic fellow at Forestry \& Forest Reproduct Res. Inst.), Dr. T. Sunose (Shirasagi Memorial Mus. of Nat. Hist.), Mr. K. Tabuchi (Chiba Univ.), Mr. K. Takahashi (Fukuoka Plant Protection Office, Chikugo Branch), Mr. S. Takasugi (Kanagawa Pref.), Mr. I. Togashi (Ishikawa Pref.), Mr. Y. Tohsaka (Kyoto Univ.), Dr. K. Yamagishi (Meijo Univ.), Mr. A. Yamamoto (Wakayama Pref.), and 
Mr. Y. Yamashita (Kanagawa Pref.). Makoto Tokuda and Nami Uechi thank Dr. O. Tadauchi, Dr. S. Kamitani, and Mr. D. Yamaguchi (Entomological Laboratory, Kyushu Univ.) for their support.

\section{References}

Hatusima, S., 1971. Flora of the Ryukyus (Including Amami Islands, Okinawa Islands, and Sakishima Archipedago). Okinawa Seibutsu Kyoiku Kenkyukai, Naha, 940pp., pls. (In Japanese.)

Horikawa, Y., 1972. Atlas of the Japanese Flora. Gakken Co., Ltd., Tokyo, 500+viiipp.

Ijichi, M., 1937. [On some galls collected from Miyazaki City and its vicinity]. Miyazaki Linné Kaiho, 8: 683. (In Japanese.)

Katanoda, I., 1999. [The Ryukyu Arc: Illustrated Book of Wild Flowers on Amami]. Nanposhinsha, Kagoshima, 221pp. (In Japanese.)

Kikuti, T., 1939. On two species of gall-midge of genus Schizomyia (Diptera, Cecidomyiidae). Annot. Zool. Jap., 18: 237-241.

Kovalev, O. V., 1964. Review on gall-midges (Diptera, Itonididae) from the extreme south of far east. I. The supertribe Asphondyliidi. Ent. Obozr., 43: 418-446. (In Russian, with English translation published in Ent.Rev., 43: 215-228.)

Miyatake, T., K. Kuba \& J. Yukawa, 2000. Seasonal occurrence of Bactrocera scutellata (Diptera: Tephritidae), a cecidophage of stem galls produced by Lasioptera sp. (Diptera: Cecidomyiidae) on wild gourds (Cucurbitaceae). Ann. Entomol. Soc. Am., 93: 1274-1279.

Monzen, K., 1937. On some new gall midges. Kontyû, 11: 180-194. (In Japanese.)

Shinji, O., 1944. [Galls and Gall Making Insects]. Shunyôdo, Tokyo, 580pp., pls. (In Japanese.)

Sunose, T., 1981. [A study of biogeography in the Izu Islands with notes on the distribution of gall midges]. Panmixia, 4: 8-12. (In Japanese.)

Sunose, T., 1982. Midge galls of Sado and Okushiri Islands (Diptera: Cecidomyiidae). Akitu, N. S., 43: 1-6.

Tamura, M., 1966. Obsevations on the plant gall of Ilex crenata Thunb. var. typica Loes. Collecting and Breeding, 28: 406-408. (In Japanese.)

Usuba, S., 1979. [Insect galls and gall-makers in Kiyosumi]. Kiyosumi, 7: 19-25. (In Japanese.)

Yamauchi, S., H. Ikenaga \& J. Yukawa, 1982. Midge galls collected from the south-west islands of Japan. Satsuma, 31: 1-23. (In Japanese with English summary.)

Yamazaki, T., 1989. Aquifoliaceae. pp. 26-32, pls., In Satake, Y., H. Hara, S. Watari and T. Tominari (eds.), Wild Flowers of Japan Woody Plants II. Heibonsha, Tokyo. (In 
Japanese.)

Yano, T., 1964. [Insect galls in Matsuyama City and its vicinity]. Ehime Koukou-Rika. 1: 66-80. (In Japanese.)

Yukawa, J., 1971. A revision of the Japanese gall midges. Mem. Fac. Agr. Kagoshima Univ., 8: 1-203.

Yukawa, J., 1976. Check list of midge galls of Japan, with descriptions of newly recorded galls. I. Choripetalae. Mem. Fac. Agr. Kagoshima Univ., 12: 109-123.

Yukawa, J., 1982. New midge galls from Japan. Mem. Fac. Agr. Kagoshima Univ., 18: 8596.

Yukawa, J., 1983. Redescriptions of three species of the genus Asteralobia (Diptera, Cecidomyiidae). Mem. Fac. Agr. Kagoshima Univ., 19: 97-108.

Yukawa, J., 1984. Geographical ecology of the butterfly fauna of the Krakatau Islands, Indonesia. Tyô to Ga, 35: 47-74.

Yukawa, J., 1988. Midge galls of Kagoshima Prefecture. Satsuma, 37: 175-205. (In Japanese.)

Yukawa, J., 1994. Midge galls newly collected from Niigata Prefecture. Spec. Bull. Essa Ent. Soc., Niigata, (2): 331-333. (In Japanese with English summary.)

Yukawa, J., M. Jaschhof, M. Tokuda \& J. Abe, 2000. Cecidomyiidae, Sciaridae (Diptera), and other galling insects than Cecidomyiidae inhabiting Fukiage-Gyoen, the Imperial Palace, Tokyo. Mem. Nat. Sci. Mus., Tokyo (36): 373-379. (In Japanese with English. summary.)

Yukawa, J. \& H. Masuda, 1996. Insect and Mite Galls of Japan in Colors. Zenkoku Nôson Kyôiku Kyôkai, Tokyo, 826pp. (In Japanese with English explanations for color plates.)

Yukawa, J. \& T. Sunose, 1979. Midge galls of Hokkaido. Mem. Fac. Agr. Kagoshima Univ., 15: 87-97.

Yukawa, J. \& T. Sunose, 1988. Midge galls of Niigata Prefecture (Diptera: Cecidomyiidae). Trans. Essa Ent. Soc., Niigata, (66): 45-58. (In Japanese with English summary.) 


$$
\text { · }
$$

